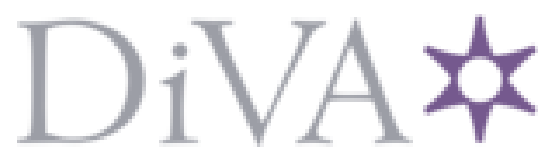

http://www.diva-portal.org

This is the published version of a paper published in Opticon 1826.

Citation for the original published paper (version of record):

Merrill, S. (2014)

New York's Subterranean Paradoxes: A Review of Subway.

Opticon 1826, (16)

http://dx.doi.org/10.5334/opt.bp

Access to the published version may require subscription.

N.B. When citing this work, cite the original published paper.

Permanent link to this version:

http://urn.kb.se/resolve?urn=urn:nbn:se:umu:diva-110021 


\title{
REVIEW
}

\section{New York's Subterranean Paradoxes: A Review of Subway}

\author{
Subway, Bruce Davidson, Aperture Foundation, 2011, 9781597111942 \\ and Subway, C/O Berlin, Germany, March 17 - May 202012
}

Samuel Merrill*

This review considers the recent re-publication of Bruce Davidson's Subway series of photographs, and their exhibition at C/O in Berlin, Germany. As such, this review positions Davidson's photographs both in relation to wider cultural analyses that highlight the paradoxical nature of subterranean space, and within a selective genealogy of subway representations. Furthermore, it views the reinvigorated interest in Davidson's work to be reflective of the growing popularity of subterranean space that has recently re-emphasised its cultural potential.

\section{Review Text}

In Notes on the Underground, Rosalind Williams establishes that subterranean space is a paradoxical site of fear and hope in addition to a popular cultural metaphor, which inspires imaginations and representations of both hell and shelter (Williams 2008). The New York subway, as Michael Brooks' Subway City demonstrates, has fluctuated between these juxtapositions. It has, at various moments, inspired contrary artistic and literary representations that are symbolic of the rise and fall of the city as a whole (Brooks 1997). Within this oscillation, Bruce Davidson's subway photographs, taken in the 1980s, present New York in decline and, also, for those who traveled on the network at that time, present its subterranean space in one of its most fear inducing states. Although Davidson is not the only individual

\footnotetext{
* Department of Geography, UCL, UK samuel.merrill.10@ucl.ac.uk.
}

to have recognised the photographic potential of the New York Subway in the 1980s, as others, including both John Conn and Jamal Shabazz also ventured into the system with their cameras, his work is perhaps the most well known.

\section{The Art of the Subway}

In 2011, an exhibition of Davidson's subway photographs in New York's Aperture Gallery was organised to coincide with the rerelease of Subway following its first publication in 1986, and its later re-issuing in 2003. More recently, forty-seven dye transfer prints went on display at the C/O Gallery in Berlin between 17 March and 20 May 2012. The prints were exhibited alongside the Claude Ventura documentary about Davidson, shot in 2010 for ARTE. Also featured were the three Subway publications. Displayed in a glass cabinet, and sharing the same image on their dust cover, these books' progressive increase in size symbolically marked 
the growing public appetite for Davidson's work. The last of these, Steidl's 2011 republication, contains over one hundred coloured photographs, including twenty-five that had not been published before. In addition, it includes a foreword from former graffiti artist, Fred Braithwaite (a.k.a. Fab 5 Freddy), an extended essay from Davidson himself, and a short reflection by the late Henry Geldzahler, the former curator of the Metropolitan Museum of Art, New York.

The inclusion of Braithwaite's commentary provides a direct connection between Davidson's photographs and the growth of subway graffiti as an element of the wider hip-hop cultural explosion in New York during the 1980s. The graffiti that permeates Davidson's work serves, recurrently, as Geldzahler reminds us, as a middle plane - an affect that the exhibition physically echoes through its use of two large graffiti covered canvases to flank its entrance. On the one hand, graffiti features as a reminder of the potential threats within the New York subway at that time, as the red spray-paint in one blurred image of a moving carriage evokes bloodshed. Though, on the other hand, it also references the subway's cultural possibilities, as exemplified by the appearance of Keith Haring's famous chalk drawings.

\section{Between Fear and Hope}

In one of his most striking images, taken whilst working for New York Magazine, Davidson captures a plainclothes police officer pointing a gun at the head of a mugger. Yet, Subway does not always so blatantly express threat and danger. Elsewhere, a woman with blonde hair and a fur coat stares directly into the lens whilst the sun sets over the New York skyline behind her. Her stare is reminiscent of that of the woman in George Tooker's 1950 painting, also named Subway, and as such, the image translates and intensifies the anxieties of that period into those of the 1980s. The silhouette of the former World Trade Center in the background provides added contemporary resonance, with its absence now being one of the main causes for anxiety in New York today.

There is, of course, also a fair share of images relating to routine. Namely, those that show the intermingled hands and arms of strap-hangers, the vacant, blank stares and newspapers of commuters, and the passengers waiting for and boarding trains. The juxtaposition of these images with those of more exceptional scenarios exemplifies what David Pike describes as "the quotidian qualities of underground space" that the subway embodies, and the otherworldly qualities it adopts when the quotidian is "beset by powerful and unforeseen forces" (Pike 2013: 227). Besides minutiae, hope and celebration also have a place in Subway. Couples and families smile for the camera, or are caught in semi-authentic moments of intimacy (Davidson would ask subjects to recreate the mood of a moment just witnessed), children are pictured on their return from Coney Island Amusement Park, and youths photographed, along with their relatives, as they prepare for graduation.

\section{Capturing Landscapes and People}

The city's skyline and landscape feature recurrently as the photographs' by-works, viewed from train windows and elevated stations, or mirrored in a network diagram, and even on the t-shirt of one of Davidson's subjects. In contrast, distant landscapes occasionally punctuate the darkness of the subterranean world and provide alternative realities for its occupants. The white sand, blue sky and sea of a Florida advertisement emphasise an escape from the city that would be out of reach for many of the subway users at this time. On occasion, the urban landscape is promoted from parergon to ergon, disrupted and dissected only by tracks and passing or oncoming carriages.

Sometimes, the human individual merges with these landscapes, blending seamlessly with their surroundings, and becoming hardly distinguishable from the muted colours and parallel lines of a carriage's window frames 
and benches. Yet, for the most part, Subway explicates its main arguments through its people. As a consequence of Davidson's reluctance to photograph covertly they are often foregrounded and alert. In this way, his work differs significantly from an earlier tradition of subway photography established by Walker Evans during the late 1930s and early 1940s (Rathbone 2000). Evans secretly captured the mundane everyday life of that period. Davidson, by comparison, has greater concern for the extraordinary, as especially demonstrated by those photographs that show: a middle-aged women lifting her dress to expose her naked body; a homeless man slumped with his trousers around his ankles; a group of scarred and tattooed youths posing menacingly; and a graffiti writer leaning towards the camera as he leaves his tag on a carriage wall.

\section{Underground Fetishes}

On the whole, Davidson's photographs exemplify the theoretical arguments attached to subterranean space by Williams and Pike. Likewise, the photographs take their place within a genealogy of representations, including those by Evans and Tooker, which illuminate the changing condition of the New York subway, as highlighted by Brooks. Yet, the images alone can be critiqued as serving primarily aesthetic, rather than documentary, ends. As Brooks argues, Davidson intended his photographs to serve as a dramatization of nightmares, which nevertheless have an uncanny beauty. In other words, Davidson urges people to lift their heads to see the beauty of the subway, no matter how unconventional it may be. However, the lack of specific chronological or geographical context, besides that provided by Davidson's personal account, can be frustrating. In both the exhibition and the catalogue, photographs are unhindered by captions, which, whilst encouraging the viewer's engagement through the formulation of imaginary or deductive narratives, does little to convey their potential documentary value. The lack of basic accompanying information is symptomatic of what this series might relate about the fetishisation of these places and their representation in the cultural present.

Davidson's work should be placed in a spectrum of global popular phenomena that acknowledges the cultural possibility of subterranean urban space. From urban exploration and organised tours of urban underworlds, to the use of such spaces as vehicles for common pastimes, interests and identification, as well as a growing academic concern for the hidden and taken-for-granted components of the city (Gandy 2002), the urban underground is experiencing a popular renaissance which is attracting the attention of a changing and growing demographic of 'subway' geeks.

Increasing global urbanization, its constituent densification, and the regulation of space perhaps encourages more of us to seek what traditionally might have be defined as 'wilderness' within our urban environments. If this scenario has credence, Davidson's work represents a lost wilderness - a time when the New York subway embodied extremes of uncertainty and possibility - and a wild environment that has become increasingly (though not entirely) flattened and tamed in the years since. For example, Braithwaite writes how subcultural graffiti in New York, "has slowed to a whisper...but rages on in major cities around the world" (cited in Davidson 2011: 7). This is especially true of Berlin, a city where the subway graffiti that spread from 1980s New York remains prevalent and culturally fertile, explaining, perhaps, the decision to host the Subway exhibition in the first place.

By extension, then, those disseminating Davidson's work might be accused of cultural fetishism. However, this accusation is perhaps more true of those who have recently started printing the photographs of his contemporary, Conn, on t-shirts, which they then sell to tourists. At its most extreme, this fetishism might cause a form of counter-nostalgia, a yearning for a time when conditions were not 
necessarily better but were pregnant with possibility. Strangely, some of Davidson's photos might leave the viewer wishing that they could escape to the subway of 1980s New York. Paradoxically, a turn of the page or a step further, has the potential to reveal a subject whose eyes and demeanor suggest that all they long for is escape - escape from their present, the present that a moment earlier had been the object of our desire.

\section{References}

Brooks, M W 1997 Subway City: Riding the Trains, Reading New York. New Brunswick, NJ: Rutgers University Press.
Davidson B 2011 Subway. Reprint ed. New York, NY: Aperture Foundation.

Gandy, M 2002 Hidden Cities. International Journal of Urban and Regional Research, 26 (1): pp. 183-188. DOI: http://dx.doi. org/10.1111/1468-2427.00372

Pike, D L 2013 London on Film and Underground. The London Journal, 38 (3): pp. 226-244. DOI: http://dx.doi.org/10.117 9/0305803413Z.00000000032

Rathbone, B 2000 Walker Evans: A Biography. New York, NY: Houghton Mifflin.

Williams, R 2008 Notes on the Underground: An Essay on Technology, Society and the Imagination. Cambridge MA: MIT Press.

How to cite this article: Merrill, S 2014 New York's Subterranean Paradoxes: A Review of Subway. Opticon1826, (16): 5, pp. 1-4, DOl: http://dx.doi.org/10.5334/opt.bp

Published: 6 March 2014

Copyright: (c) 2014 The Author(s). This is an open-access article distributed under the terms of the Creative Commons Attribution 3.0 Unported License (CC-BY 3.0), which permits unrestricted use, distribution, and reproduction in any medium, provided the original author and source are credited. See http://creativecommons.org/licenses/by/3.0/. 